\title{
Myeloid Dendritic Cells are Potential Players in Human Neurodegenerative Diseases
}

\author{
Paola Bossù̀ ${ }^{*}$, Gianfranco Spalletta ${ }^{1,2}$, Carlo Caltagirone ${ }^{1,3}$ and Antonio Ciaramella ${ }^{1}$ \\ ${ }^{1}$ Department of Clinical and Behavioral Neurology, IRCCS Santa Lucia Foundation, Rome, Italy, ${ }^{2}$ Menninger Department of \\ Psychiatry and Behavioral Sciences, Baylor College of Medicine, Houston, TX, USA, ${ }^{3}$ Department of Neuroscience, \\ University of Rome Tor Vergata, Rome, Italy
}

\section{OPEN ACCESS}

Edited by: Eva Rajnavolgyi,

University of Debrecen, Hungary

Reviewed by:

Mohey Eldin El Shikh,

Queen Mary University of London,

Julie Tabiasco, INSERM, France

*Correspondence:

Paola Bossù

p.bossu@hsantalucia.it

Specialty section:

This article was submitted to Multiple Sclerosis and Neuroimmunology,

a section of the journal

Frontiers in Immunology

Received: 01 October 2015 Accepted: 02 December 2015 Published: 16 December 2015

Citation:

Bossù P, Spalletta G, Caltagirone $C$ and Ciaramella A (2015) Myeloid Dendritic Cells are Potential Players in Human Neurodegenerative Diseases.

Front. Immunol. 6:632. doi: 10.3389/fimmu.2015.00632
Alzheimer's diseases (AD) and Parkinson's diseases (PD) are devastating neurodegenerative disturbances, wherein neuroinflammation is a chronic pathogenic process with high therapeutic potential. Major mediators of $\mathrm{AD} / \mathrm{PD}$ neuroimmune processes are resident immune cells, but immune cells derived from periphery may also participate and to some extent modify neuroinflammation. Specifically, blood borne myeloid cells emerge as crucial components of AD/PD progression and susceptibility. Among these, dendritic cells (DCs) are key immune orchestrators and players of brain immune surveillance; we candidate them as potential mediators of both $A D$ and PD and as relevant cell model for unraveling myeloid cell role in neurodegeneration. Hence, we recapitulate and discuss emerging data suggesting that blood-derived DCs play a role in experimental and human neurodegenerative diseases. In humans, in particular, DCs are modified by in vitro culture with neurodegeneration-associated pathogenic factors and dysregulated in AD patients, while the levels of DC precursors are decreased in AD and PD patients' blood, possibly as an index of their recruitment to the brain. Overall, we emphasize the need to explore the impact of DCs on neurodegeneration to uncover peripheral immune mechanisms of pathogenic importance, recognize potential biomarkers, and improve therapeutic approaches for neurodegenerative diseases.

Keywords: Alzheimer's disease, Parkinson's disease, blood-derived myeloid cells, monocyte-derived dendritic cells, dendritic cell precursors, blood DCs

\section{INTRODUCTION}

Neurodegeneration is a pathologic process leading to the loss of structure and function of neuronal tissue. The two most frequent neurodegenerative disturbances affecting humans are Alzheimer's (AD) and Parkinson's disease (PD), respectively, leading to dementia and movement disorders. They are age-dependent and progressive diseases with distinct clinical and pathological features and different types of neurons and brain areas resulting affected, but with some overlapping pathologic mechanisms. Both diseases are typified by the presence in the brain of the peculiar age-related accumulation of specific misfolded molecules, namely amyloid $\beta$ peptides $(\mathrm{A} \beta)$ and tau protein in AD, and $\alpha$-synuclein protein ( $\alpha$-syn) in PD. Such molecules are widely hypothesized to be primary cause of disease and appear implicated in several key pathogenic mechanisms (1, 2). The presence of abnormal molecular deposits is accompanied by the activation of resident brain immune cells (microglia) and release of pro-inflammatory mediators. Thus, despite both 
disturbances appear primarily triggered by non-immune causes, inflammation has been increasingly described as a common and central pathogenic factor of the neurodegenerative process (3-5). It is generally accepted that an impaired ability of brain immune cells to clear dangerous substances and damaged tissue promotes the establishment of inflammation, whose persistence in turn may lead to neurodegeneration progression through a self-perpetuating chronic process that ends up with brain tissue damage, but the precise mechanisms underlying the multifaceted role of inflammation in the disease are still intensely debated $(6,7)$. Recent genetic and expression studies have identified a number of genes connected with inflammation and immune response as risk factors for the development of both $\mathrm{AD}$ and $\mathrm{PD}$ $(8,9)$, reinforcing the view that inflammation is a major causative factor and not just a consequence of neurodegeneration. This is especially true in the sporadic forms of $\mathrm{AD} / \mathrm{PD}$, which are much more common than the familial forms (10-12). Furthermore, the use of anti-inflammatory drugs may delay or prevent the onset of $\mathrm{AD}$ and $\mathrm{PD}$, validating the concept that inflammation is a good therapeutic target (13-15), even though some clinical trials generated disappointing results (16). Such inconsistency is attributed to the incomplete understanding of the interactions occurring between immunity and central nervous system (CNS), including the potential regulative functions of blood-derived immune cells (17). In this regard, the modern concept of the brain's immune privilege based on a dynamic interaction between peripheral immune system and CNS $(18,19)$ and the very recent discovery of meningeal lymphatic vessels in the brain (20) validate the idea that the bidirectional communication between CNS and systemic immunity is more resourceful than before considered. Although no massive infiltration of blood-derived immune cells is reported in neurodegeneration, it is growing the thought that the recruitment of bone marrow-derived immunocompetent cells from the systemic circulation to the brain is an important event, which could regulate neuroinflammatory response and influence neurodegeneration (21).

Given such premises, dendritic cells (DCs), acting as key controllers of the immune response and inflammation, may be crucially involved in maintaining brain immune surveillance, helping resident microglia in response to insults, and regulating the local and systemic immune response during neuroinflammation (22). Here, we will examine the current evidence that converges to propose DCs as potential disease-relevant cell types in both $\mathrm{AD}$ and PD.

\section{PERIPHERALLY DERIVED IMMUNE CELLS IN NEURODEGENERATION}

Microglia, the brain-resident mononuclear phagocytic cells, play a central role in $\mathrm{AD}$ and $\mathrm{PD}$ chronic inflammation, with insights in disease susceptibility, pathophysiology, diagnosis, prognosis, and therapy (23). Although normally microglia have a protective role linked to their ability to clear harmful material, their activation in $\mathrm{AD}$ and PD has been related to the brain accumulation of abnormally aggregated proteins, increased production of inflammatory factors, and neuronal loss. More recent data suggest that during neurodegeneration, microglia acquire a dysfunctional rather than activated phenotype, characterized by defective clearance and loss of neuronal support capability. Although microglia are main drivers of neurodegenerative disease, their precise role is still a matter of debate and, importantly, it is now emerging that they may not be the only effectors of brain immune response. Sustained by the revised concept of the immunoprivileged brain, a contribution to neurodegeneration of additional mediators of the innate immune system beside microglia is widely hypothesized $(17,24)$, and systemic inflammation is considered an exacerbating force in neurodegenerative diseases $(25,26)$.

The notions that aging and neuroinflammation promote disturbance of the blood-brain barrier (BBB) and that neurovascular dysfunctions lead to alteration of the crosstalk between different cell types at the brain-blood interface in both $\mathrm{AD}$ and $\operatorname{PD}(27,28)$ make conceivable the participation of peripheral cells in neurodegeneration.

Myeloid cells that can mediate the brain innate immune response beside microglia include perivascular cells, meningeal macrophages and blood-borne monocytes, macrophages, and DCs. All these cell types are not homogeneous populations; they differ in terms of origin, function, and fate, respond in a variable way to environmental changes, and act in concert during neurodegeneration (29). While the characteristics of the different myeloid cell populations participating in brain homeostasis and inflammation have been reported elsewhere (30), here we describe some of the most recent evidence sustaining the value of blood-derived monocytic cells in AD and PD.

Many of the genes recently identified to be associated with both familial and sporadic forms of $\mathrm{AD}$ and $\mathrm{PD}$ have been found to be also expressed and play important roles in peripheral innate immune cells. Specifically, CD33 and TREM2 gene variants have been reported as significant risk factors for $\operatorname{AD}(31,32)$ and associated also with PD (33). These genes are strictly coupled with myeloid cell functions leading to the clearance of misfolded molecules, and are expressed, other than on microglia, also on peripheral myeloid cells. Consistently, a gene expression profile study shows overexpression of $\mathrm{AD}$ and PD risk alleles specifically in patients' blood monocytes (34).

Several studies report that monocytic cells, able to infiltrate the degenerated brain following specific signaling pathways, may be capable to modulate $\mathrm{AD}$ progression (35). Consistently, in real-time in vivo imaging studies, vascular $A \beta$ clearance is carried out by patrolling monocytes (36), according to previous results showing that peripherally derived myeloid cells are protective in $\mathrm{AD}$ through mechanisms of brain recruitment involving MCP-1 chemotaxis (37-39). At variance, peripherally derived macrophages have a detrimental role in TREM2-deficient AD mice (40), suggesting that the function of infiltrating myeloid cells may be complex and dependent on cell subset and inflammatory context considered. Clinical evidence on the involvement of peripherally derived mononuclear phagocytes comes from the observations that $\mathrm{AD}$ macrophages infiltrate the brain and damage the BBB, and in the blood they show abnormal cytokines release, increased apoptosis, and impaired ability to engulf $A \beta$ (41, 42). Regarding PD, monocyte infiltration is involved in aggravation of neurodegeneration in murine transgenic models 
(43). Similarly, circulating blood monocytes have been found altered in PD patients as for transcriptome profile and function, and their hyperactivity has been shown to correlate with disease severity (44). Consistently with AD, the CCL2-CCR2 system appears to play a dominant role also in monocyte recruitment to PD patients' brain (45). However, the precise identity and dynamic of infiltrating myeloid immune cell subpopulations as well as their role in the disease context is to date still vague. In fact, despite novel molecular biological tools have shed some light on the origin and functions of microglia versus other myeloid cell populations in the CNS (46), the identification of infiltrating myeloid subsets (including DCs) is hard in neurodegeneration, especially in humans, where restricted cell numbers, high morphological and functional heterogeneity linked to environmental changes, and lack of specific markers (47) prevent to make accurate distinctions.

\section{EVIDENCE FOR DENDRITIC CELL PARTICIPATION IN NEURODEGENERATION}

Dendritic cells are chief orchestrators of the immune response and main link between innate and adaptive immune response (48). They form a heterogeneous cell population, located in different body tissues, with diverse immunological functions. Considering the main properties of DCs, such as migratory abilities, pivotal role in looking out potentially harmful factors, and ability to regulate both innate and acquired immunity and to resolve responses potentially harmful if left uncontrolled, they may be key players in brain immune surveillance and good candidates as participants in neuroinflammation and neurodegeneration. Linked to their key activity to educate $\mathrm{T}$ cells in driving the immune response, DCs may stimulate lymphocytes during their entry into brain and activate an adaptive immune response during $\mathrm{AD}$ and $\mathrm{PD}$ pathogenic processes. Indeed, dysregulation of the adaptive immune response, in terms of abnormal brain $\mathrm{T}$ cell activation and infiltration, has been reported in both experimental and human conditions of AD and PD (49-53).

\section{Brain DCs}

Regarding the identification of DCs in the brain, as exhaustively reviewed by Colton (54), a number of studies mainly performed in animals have provided evidence for their presence within CNS. Generally defined as brain DCs, these cells have dendritic morphology and express major histocompatibility complex class II molecules (MHCII) and leukocyte integrin CD11c, are heterogeneous and may exert complex immunological functions, and likely derive from circulating DC precursors, rather than from within the brain, as suggested by their juxtavascular location in the meninges and the choroid plexus (55). Brain DCs are present in CNS compartments, including cerebral spinal fluid (CSF), meninges, choroid plexus, and perivascular spaces of both rodents and humans (56-58), where they may act as immune sentinels at the interfaces between the brain and periphery. Although low in the steady state, DCs' frequency increases in CNS under neuroinflammatory conditions $(57,59,60)$ and during aging $(61)$, raising the possibility of their participation in neurodegenerative processes.

Though the DC presence in AD or PD brain parenchyma has not definitively proved so far, it has been hypothesized in murine models of $\mathrm{AD}$ (62), demonstrated in aged yellow fluorescent protein transgenic mice (61) and only guessable in postmortem human $\mathrm{AD}$ brain tissue, where in glial cells, a phenotypic change, recalling that of activated DCs, was observed (63).

While protective activities linked to their ability to clear $\mathrm{A} \beta$ have been suggested for $\mathrm{CD} 11 \mathrm{c}^{+}$cells in $\mathrm{AD}$ mouse models (64, 65 ), indirect data suggest that DCs are pivotal in $\mathrm{PD}$ pathogenesis, where an immune response to self-antigens may be a causative factor $(66,67)$.

Additional insights about DC participation in human neurodegeneration come from in vitro experiments addressed to explore how A $\beta$ peptides impact DC function in humans, as well as from in vivo analysis of DC precursors' frequency in blood of patients with neurodegeneration (Table 1).

\section{In vitro Monocyte-Derived DCs}

As renowned cell model to analyze human DC functional response (73), in vitro-generated monocyte-derived DCs (moDCs) have been used under neurodegenerative specific conditions. MoDCs triggered with $A \beta_{25-35}$ peptide show only a slight decrease in surface expression of MHCII (68). At variance, when the same cells are differentiated in the presence of $A \beta_{1-42}$ in a long-lasting stimulation state, which presumably better mimics AD conditions, $\mathrm{A} \beta$ induces increase in cell survival and soluble antigen uptake, elevated production of IL-1 $\beta$, IL-6, and IL-18, but a decrease in MHC expression and ability to activate T cells (69). Interestingly, moDCs obtained from $\mathrm{AD}$ patients, as compared to age-matched control subjects, show more pronounced pro-inflammatory features and reduced antigen-presenting ability (70), and notably they produce lower levels of BDNF following $A \beta_{1-42}$ stimulation (71). All together, these findings, other than advocate for the suitability of this cell model to investigate the mechanisms of myeloid involvement in neurodegeneration, also indicate that under AD conditions, DCs might contribute to brain damage by mechanisms of overactivation of inflammatory responses and A $\beta$-mediated reduction of trophic support to neurons, suggesting that they may be mediators of $\mathrm{AD}$ neurodegeneration.

\section{Blood DCs}

To exercise their ability to survey the brain and activate adaptive immune response, precursors of DCs should migrate from the bone marrow to CNS sites. In humans, the most suitable populations of circulating cells with such features are the two main subpopulations of blood immature DCs, namely myeloid (mDCs; lin $^{-} \mathrm{CD}_{11 \mathrm{c}^{+}} \mathrm{MHCII}^{\mathrm{hi}}, \mathrm{CD} 123^{\mathrm{lo}}$ ) and plasmacytoid (pDCs; lin ${ }^{-}$

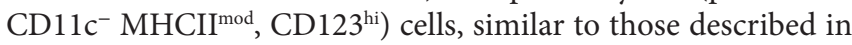
the $\operatorname{CSF}(57,74,75)$. Thus, to confirm the potential relevance of DCs in neurodegenerative diseases, frequency and phenotypic abnormalities of the two blood DC precursor subsets, mDCs and pDCs, and their relationships with disease outcome have been evaluated in both $\mathrm{AD}$ and $\mathrm{PD}$ patients. Preliminary results from our research group indicate a significant drop of myeloid DC precursors in blood of $\mathrm{AD}$ patients, occurring in association with 
TABLE 1 | In vitro and in vivo evidence for DC participation in human neurodegenerative diseases.

\begin{tabular}{|c|c|c|c|c|c|}
\hline Disease & DC type & Model & Analysis & Main finding & Reference \\
\hline \multirow[t]{5}{*}{$A D$} & $\begin{array}{l}\text { Monocyte- } \\
\text { derived }\end{array}$ & In vitro triggering with $A \beta_{25-35}$ & $\begin{array}{l}\text { Phenotype, cytokine production, } T \text { cell } \\
\text { activation }\end{array}$ & $\downarrow \mathrm{MHCl}$ & Schmitt et al. (68) \\
\hline & $\begin{array}{l}\text { Monocyte- } \\
\text { derived }\end{array}$ & $\begin{array}{l}\text { In vitro generation with } A \beta_{1-42} \\
\text { (long lasting stimulation) }\end{array}$ & $\begin{array}{l}\text { Phenotype, phagocytosis, cytokine } \\
\text { production, T cell activation }\end{array}$ & $\begin{array}{l}\uparrow \text { Cell recovery; } \uparrow \text { antigen uptake; } \uparrow \text { IL-1 } \beta / \mathrm{IL}-6 / \\
\text { IL-18; } \downarrow \text { IL-12/IL-10; } \downarrow \text { MHCII; } \downarrow \text { APC ability }\end{array}$ & $\begin{array}{l}\text { Ciaramella et al. } \\
(69)\end{array}$ \\
\hline & $\begin{array}{l}\text { Monocyte- } \\
\text { derived }\end{array}$ & $\begin{array}{l}\text { In vitro generation from } \mathrm{AD} \\
\text { patients' monocytes }\end{array}$ & $\begin{array}{l}\text { Phenotype, phagocytosis, cytokine } \\
\text { production, T cell activation }\end{array}$ & $\begin{array}{l}\uparrow \text { Cell recovery; } \uparrow \text { ICAM-1; } \uparrow I L-6 ; \downarrow \text { CD40; } \\
\downarrow \text { APC ability }\end{array}$ & $\begin{array}{l}\text { Ciaramella et al. } \\
(70)\end{array}$ \\
\hline & $\begin{array}{l}\text { Monocyte- } \\
\text { derived }\end{array}$ & $\begin{array}{l}\text { In vitro generation from } A D \\
\text { patients' monocytes triggering } \\
\text { with } A \beta_{1-42}\end{array}$ & $\begin{array}{l}\text { Phenotype, phagocytosis, cytokine/ } \\
\text { neurotrophin production, T cell } \\
\text { activation }\end{array}$ & $\downarrow \mathrm{BDNF}$ & $\begin{array}{l}\text { Ciaramella et al. } \\
(71)\end{array}$ \\
\hline & $\begin{array}{l}\text { Blood } \\
\text { precursors }\end{array}$ & $\begin{array}{l}\text { Ex vivo precursors from } A D \\
\text { patients' blood }\end{array}$ & $\begin{array}{l}\text { Flow cytometry in blood cells (Lin 1\% } \\
\mathrm{MHCl}^{+} / \mathrm{CD} 11 \mathrm{C}^{+} \text {or } \mathrm{CD} 123^{+} \text {) }\end{array}$ & $\begin{array}{l}\downarrow \text { mDCs; association with AD symptom } \\
\text { severity }\end{array}$ & $\begin{array}{l}\text { Ciaramella et al. } \\
\text { (2015, submitted) }\end{array}$ \\
\hline PD & $\begin{array}{l}\text { Blood } \\
\text { precursors }\end{array}$ & $\begin{array}{l}\text { Ex vivo precursors from PD } \\
\text { patients' blood }\end{array}$ & $\begin{array}{l}\text { Flow cytometry in blood cells (Lin 1\% } \\
\mathrm{MHCll}^{+} / \mathrm{CD} 11 \mathrm{C}^{+} \text {or } \mathrm{CD} 123^{+} \text {) }\end{array}$ & $\begin{array}{l}\downarrow \text { mDCs; } \downarrow \text { pDCs; association with PD } \\
\text { symptom severity }\end{array}$ & $\begin{array}{l}\text { Ciaramella et al. } \\
(72)\end{array}$ \\
\hline
\end{tabular}

increased severity of disease symptoms (Ciaramella et al. 2015, submitted). Similarly, blood DC levels, regarding both $\mathrm{mDC}$ and pDC subsets, are decreased in PD patients in association with increased impairment of motor functions, suggesting innovative exploitations of DC monitoring as a clinically significant tool for neurodegenerative diseases (72). Although the reduction of blood DCs may be due to different circumstances, including alterations in either viability, mobilization, or differentiation of DCs from their progenitors, it may likely depend on their recruitment from circulation to degenerating brain, similarly to what observed also in other brain diseases.

Collectively, the above described in vitro and in vivo human studies lead to speculate that in $\mathrm{AD}$ and $\mathrm{PD}$, a percentage of blood DCs moving from peripheral blood may reach the brain of patients, probably at choroid plexus or meninges level, where they may sample CSF content for brain antigens (including $A \beta$ ), acquire a dysregulated phenotype, and contribute to the inflammatory milieu, playing a putative pathological role in neurodegeneration, as depicted in Figure 1.

Additional studies should be addressed to better understand whether, after reaching the brain, DCs may function to locally regulate infiltrating activated $\mathrm{T}$ cells or carry antigens to CNSdraining cervical lymph nodes. Furthermore, although an active research is addressed to specifically understand how adaptive immune response participates in this scenario (76), details about DC role in orchestrating the induction of immunity and tolerance in neurodegenerative diseases are so far unknown.

\section{POTENTIAL THERAPEUTIC USES OF DENDRITIC CELLS IN NEURODEGENERATION}

Given the potential key role of DCs in regulating brain immune response during neurodegeneration, these cells should be considered as potentially useful target for therapeutic approach of neurodegenerative diseases. Nearly all studies in this direction regard the use of DCs as tools for vaccination purposes, rather than targets to modify the immune responses, since the latter issue is still far from being resolved. Several optimized immunization approaches addressed to eliminate accumulation of misfolded proteins have been considered in the last years as a promising therapeutic strategy for neurodegenerative diseases. DCs may be good candidates as potent antigen-presenting cells appropriately loaded in vitro with suitable peptides of misfolded proteins, and made able to preferentially elicit a non-inflammatory-specific immune response (77). Thus, in $\mathrm{AD}$ animals, $\mathrm{A} \beta$-sensitized DCs have been used to reduce $A \beta$ accumulation and attenuate cognitive deficits (78), and to prevent AD pathology when used in combination with other cells to reverse immunosenescence (79). A recent study addressed to investigate the molecular mechanisms allowing $\mathrm{T}$ cells to specifically target $\mathrm{A} \beta$-loaded brain areas following $\mathrm{A} \beta$ immunization of $\mathrm{AD}$ mice proposes that DCs play a role in regulating $A \beta$-specific $T$-cell entry into the brain at leptomeningeal and perivascular spaces (80). Similarly to the $\mathrm{AD}$ state, the removal of $\alpha$-Syn has been assumed to have the potential to modify the course of $\mathrm{PD}$, and $\alpha$-Syn-stimulated DCs injected into PD transgenic mice induce the production of anti- $\alpha$-Syn antibodies and improve the animal locomotor functions (81). The proposed therapeutic use of DCs, as suggested by animal studies, is illustrated in Figure 1B (right hand side). However, in order to translate into clinic, further studies are needed to verify in humans the potential ability of this approach to both provide an effective adaptive immune response against misfolded proteins and counteract the putative pathological role of endogenously dysregulated DCs.

\section{CONCLUDING REMARKS}

Within an evolving picture of the immune-to-brain crosstalk, the systemic immune response appears integral to the function of brain-resident immune cells during neurodegeneration, with myeloid immune cells holding a pivotal role. Among those, blood-derived DCs may participate, though their involvement in neurodegeneration awaits experimental verification, especially in humans. The advent of new potent technological tools, including microarray technology, next generation sequencing transcriptome, and epigenetic analysis, may help in identifying the function of DCs in the initiation and/or regulation of the brain-specific immune response. 

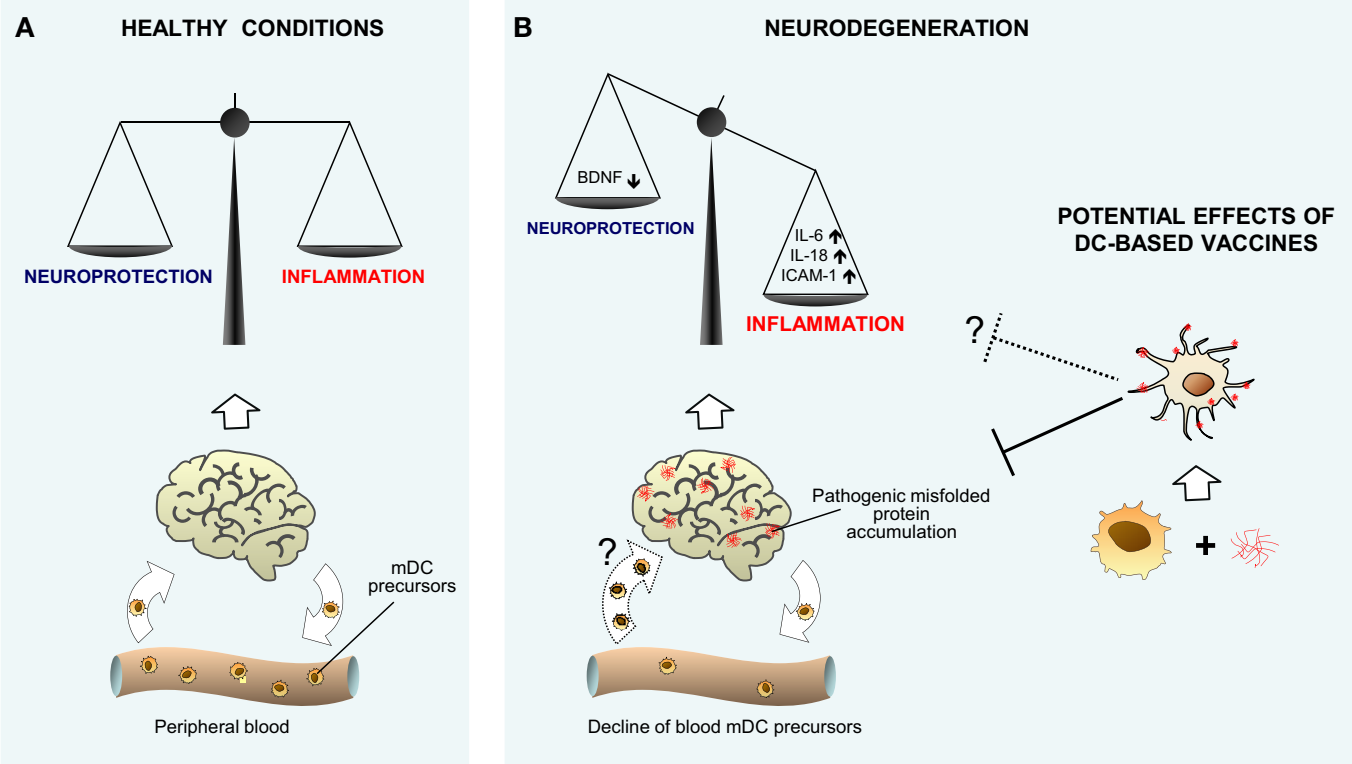

FIGURE 1 | Hypothetical model showing the role of myeloid DCs in neurodegenerative diseases. The cartoon recapitulates our view of the potential role of myeloid DCs in neurodegenerative diseases, as both possible participants in promoting inflammatory neuroimmune processes, and supposed tools to perform vaccine therapy. (A) Given their nature as key controllers of the immune response and inflammation, mDCs may participate in maintaining brain immune surveillance and controlling the delicate homeostatic balance between protective and inflammatory neuroimmune processes in normal healthy conditions. (B) As suggested by human in vitro data, during neurodegeneration, mDCs may be involved in promoting imbalance between protective and inflammatory neuroimmune processes. The decline of DC precursors observed in vivo in peripheral blood of patients with neurodegenerative diseases may be a consequence of cell recruitment to the diseased brain (illustrated as a dotted arrow), where DCs may acquire a dysregulated phenotype and contribute to the inflammatory milieu. The potential therapeutic use of DC vaccination in neurodegeneration is depicted [right hand side of (B)] on the basis of animal models' results. Myeloid DCs differentiated and expanded from peripheral precursors, and specifically targeted in vitro against misfolded proteins, may trigger an immune response that promotes the clearance of brain aggregates and attenuates symptoms, possibly even restoring the neuroinflammatory homeostasis (illustrated as a dotted line).

In conclusion, answering the questions about DC infiltration in $\mathrm{AD} / \mathrm{PD}$ brain and $\mathrm{DC}$ function in human disease progression might be essential for neurologists to better understand the neurodegeneration pathophysiology, develop biomarkers, and improve therapeutic approaches for the most common and devastating neurodegenerative diseases of the modern society.

\section{AUTHOR CONTRIBUTIONS}

$\mathrm{PB}, \mathrm{GS}, \mathrm{CC}$, and AC provided substantial contribution to the conception and design of the manuscript. $\mathrm{PB}$ drafted the

\section{REFERENCES}

1. Selkoe DJ. Cell biology of protein misfolding: the examples of Alzheimer's and Parkinson's diseases. Nat Cell Biol (2004) 6(11):1054-61. doi:10.1038/ ncb1104-1054

2. Goedert M. Alzheimer's and Parkinson's diseases: the prion concept in relation to assembled A $\beta$, tau, and $\alpha$-synuclein. Science (2015) 349(6248):1255555. doi:10.1126/science. 1255555

3. Hirsch EC, Hunot S. Neuroinflammation in Parkinson's disease: a target for neuroprotection? Lancet Neurol (2009) 8(4):382-97. doi:10.1016/ S1474-4422(09)70062-6

4. Glass CK, Saijo K, Winner B, Marchetto MC, Gage FH. Mechanisms underlying inflammation in neurodegeneration. Cell (2010) 140:918-34. doi:10.1016/j.cell.2010.02.016 manuscript and $\mathrm{PB}, \mathrm{GS}, \mathrm{CC}$, and $\mathrm{AC}$ revise it critically for important intellectual content. $\mathrm{PB}, \mathrm{GS}, \mathrm{CC}$, and $\mathrm{AC}$ provided the final approval of the version should be published. PB, GS, $\mathrm{CC}$, and AC agreed to be accountable for all aspects of the work in ensuring that questions related to the accuracy or integrity of any part of the work are appropriately investigated and resolved.

\section{FUNDING}

This project was supported by the Italian Ministry of Health.

5. Heppner FL, Ransohoff RM, Becher B. Immune attack: the role of inflammation in Alzheimer disease. Nat Rev Neurosci (2015) 16(6):358-72. doi:10.1038/ nrn3880

6. Czirr E, Wyss-Coray T. The immunology of neurodegeneration. J Clin Invest (2012) 122:1156-63. doi:10.1172/JCI58656

7. Heneka MT, Carson MJ, El Khoury J, Landreth GE, Brosseron F, Feinstein DL, et al. Neuroinflammation in Alzheimer's disease. Lancet Neurol (2015) 14:388-405. doi:10.1016/S1474-4422(15)70016-5

8. Hamza TH, Zabetian CP, Tenesa A, Laederach A, Montimurro J, Yearout D, et al. Common genetic variation in the HLA region is associated with late-onset sporadic Parkinson's disease. Nat Genet (2010) 42(9):781-5. doi:10.1038/ ng. 642

9. International Genomics of Alzheimer's Disease Consortium (IGAP). Convergent genetic and expression data implicate immunity in Alzheimer's 
disease. Alzheimers Dement (2015) 11(6):658-71. doi:10.1016/j. jalz.2014.05.1757

10. Deleidi $\mathrm{M}$, Gasser $\mathrm{T}$. The role of inflammation in sporadic and familial Parkinson's disease. Cell Mol Life Sci (2012) 70(22):4259-73. doi:10.1007/ s00018-013-1352-y

11. Krstic D, Knuesel I. Deciphering the mechanism underlying late-onset Alzheimer disease. Nat Rev Neurol (2013) 9(1):25-34. doi:10.1038/ nrneurol.2012.236

12. Karch CM, Goate AM. Alzheimer's disease risk genes and mechanisms of disease pathogenesis. Biol Psychiatry (2015) 77:43-51. doi:10.1016/j. biopsych.2014.05.00

13. Chen H, Jacobs E, Schwarzschild MA, McCulloch ML, Calle EE, Thun MJ, et al. Nonsteroidal anti-inflammatory drugs and the risk for Parkinson's disease. Ann Neurol (2005) 58:963-7. doi:10.1002/ana.20682

14. Gagne JJ, Power MC. Anti-inflammatory drugs and risk of Parkinson disease: a meta-analysis. Neurology (2010) 74:995-1002. doi:10.1212/ WNL.0b013e3181d5a4a3

15. Vlad SC, Miller DR, Kowall NW, Felson DT. Protective effects of NSAIDs on the development of Alzheimer disease. Neurology (2008) 70:1672-7. doi:10.1212/01.wnl.0000311269.57716.63

16. ADAPT Research Group, Martin BK, Szekely C, Brandt J, Piantadosi S, Breitner JC, et al. Cognitive function over time in the Alzheimer's disease anti-inflammatory prevention trial (ADAPT): results of a randomized, controlled trial of naproxen and celecoxib. Arch Neurol (2008) 65(7):896-905. doi:10.1001/archneur.2008.65.7.nct70006

17. Schwartz M, Shechter R. Systemic inflammatory cells fight off neurodegenerative disease. Nat Rev Neurol (2010) 6:405-10. doi:10.1038/nrneurol.2010.71

18. Carson MJ, Doose JM, Melchior B, Schmid CD, Ploix CC. CNS immune privilege: hiding in plain sight. Immunol Rev (2006) 213:48-65. doi:10.1111/j.1600-065X.2006.00441.x

19. McAllister AK, van de Water J. Breaking boundaries in neural-immune interactions. Neuron (2009) 64(1):9-12. doi:10.1016/j.neuron.2009.09.038

20. Louveau A, Smirnov I, Keyes TJ, Eccles JD, Rouhani SJ, Peske JD, et al. Structural and functional features of central nervous system lymphatic vessels. Nature (2015) 523(7560):337-41. doi:10.1038/nature14432

21. Rezai-Zadeh K, Gate D, Town T. CNS infiltration of peripheral immune cells: d-day for neurodegenerative disease? J Neuroimmune Pharmacol (2009) 4(4):462-75. doi:10.1007/s11481-009-9166-2

22. D’Agostino PM, Gottfried-Blackmore A, Anandasabapathy N, Bulloch K. Brain dendritic cells: biology and pathology. Acta Neuropathol (2012) 124(5):599-614. doi:10.1007/s00401-012-1018-0

23. Ransohoff RM, Perry VH. Microglial physiology: unique stimuli, specialized responses. Annu Rev Immunol (2009) 27:119-45. doi:10.1146/annurev. immunol.021908.132528

24. Rivest S. Regulation of innate immune responses in the brain. Nat Rev Immunol (2009) 9(6):429-39. doi:10.1038/nri2565

25. Hernández-Romero MC, Delgado-Cortés MJ, Sarmiento M, de Pablos RM, Espinosa-Oliva AM, Argüelles S, et al. Peripheral inflammation increases the deleterious effect of CNS inflammation on the nigrostriatal dopaminergic system. Neurotoxicology (2012) 33(3):347-60. doi:10.1016/j.neuro.2012.01.018

26. Perry VH, Holmes C. Microglial priming in neurodegenerative disease. Nat Rev Neurol (2014) 10(4):217-24. doi:10.1038/nrneurol.2014.38

27. Desai BS, Monahan AJ, Carvey PM, Hendey B. Blood-brain barrier pathology in Alzheimer's and Parkinson's disease: implications for drug therapy. Cell Transplant (2007) 16(3):285-99. doi:10.3727/000000007783464731

28. Zlokovic BV. Neurovascular pathways to neurodegeneration in Alzheimer's disease and other disorders. Nat Rev Neurosci (2011) 12(12):723-38. doi:10.1038/nrn3114

29. Prinz M, Priller J, Sisodia SS, Ransohoff RM. Heterogeneity of CNS myeloid cells and their roles in neurodegeneration. Nat Neurosci (2011) 14(10):122735. doi:10.1038/nn.2923

30. Greter M, Lelios I, Croxford AL. Microglia versus myeloid cell nomenclature during brain inflammation. Front Immunol (2015) 6:249. doi:10.3389/ fimmu.2015.00249

31. Bradshaw EM, Chibnik LB, Keenan BT, Ottoboni L, Raj T, Tang A, et al. CD33Alzheimer's disease locus: altered monocyte function and amyloid biology. Nat Neurosci (2013) 16(7):848-50. doi:10.1038/nn.3435
32. Jonsson T, Stefansson H, Steinberg S, Jonsdottir I, Jonsson PV, Snaedal J, et al. Variant of TREM2 associated with the risk of Alzheimer's disease. $N$ Engl J Med (2013) 368(2):107-16. doi:10.1056/NEJMoa1211103

33. Rayaprolu S, Mullen B, Baker M, Lynch T, Finger E, Seeley WW, et al. TREM2 in neurodegeneration: evidence for association of the $\mathrm{p}$. $\mathrm{R} 47 \mathrm{H}$ variant with frontotemporal dementia and Parkinson's disease. Mol Neurodegener (2013) 8:19. doi:10.1186/1750-1326-8-19

34. Raj T, Rothamel K, Mostafavi S, Ye C, Lee MN, Replogle JM, et al. Polarization of the effects of autoimmune and neurodegenerative risk alleles in leukocytes. Science (2014) 344(6183):519-23. doi:10.1126/science.1249547

35. Malm T, Koistinaho M, Muona A, Magga J, Koistinaho J. The role and therapeutic potential of monocytic cells in Alzheimer's disease. Glia (2010) 58(8):889-900. doi:10.1002/glia.20973

36. Michaud JP, Bellavance MA, Prefontaine P, Rivest $S$. Real-time in vivo imaging reveals the ability of monocytes to clear vascular amyloid $\beta$. Cell Rep (2013) 5:646-53. doi:10.1016/j.celrep.2013.10.010

37. Simard AR, Soulet D, Gowing G, Julien JP, Rivest S. Bone marrow-derived microglia play a critical role in restricting senile plaque formation in Alzheimer's disease. Neuron (2006) 49:489-502. doi:10.1016/j.neuron.2006.01.022

38. El Khoury J, Toft M, Hickman SE, Means TK, Terada K, Geula C, et al. Ccr2 deficiency impairs microglial accumulation and accelerates progression of Alzheimer-like disease. Nat Med (2007) 13(4):432-8. doi:10.1038/nm1555

39. Mildner A, Schlevogt B, Kierdorf K, Böttcher C, Erny D, Kummer MP, et al. Distinct and non-redundant roles of microglia and myeloid subsets in mouse models of Alzheimer's disease. J Neurosci (2011) 31(31):11159-71. doi:10.1523/JNEUROSCI.6209-10.2011

40. Jay TR, Miller CM, Cheng PJ, Graham LC, Bemiller S, Broihier ML, et al. TREM2 deficiency eliminates TREM2+ inflammatory macrophages and ameliorates pathology in Alzheimer's disease mouse models. J Exp Med (2015) 212(3):287-95. doi:10.1084/jem.20142322

41. Fiala M, Liu QN, Sayre J, Pop V, Brahmandam V, Graves MC, et al. Cyclooxygenase-2-positive macrophages infiltrate the Alzheimer's disease brain and damage the blood-brain barrier. Eur J Clin Invest (2002) 32(5):36071. doi:10.1046/j.1365-2362.2002.00994.x

42. Fiala M, Lin J, Ringman J, Kermani-Arab V, Tsao G, Patel A, et al. Ineffective phagocytosis of amyloid-beta by macrophages of Alzheimer's disease patients. J Alzheimers Dis (2005) 7(3):221-32.

43. Gao L, Brenner D, Llorens-Bobadilla E, Saiz-Castro G, Frank T, Wieghofer P, et al. Infiltration of circulating myeloid cells through CD95L contributes to neurodegeneration in mice. J Exp Med (2015) 212(4):469-80. doi:10.1084/ jem. 20132423

44. Grozdanov V, Bliederhaeuser C, Ruf WP, Roth V, Fundel-Clemens K, Zondler L, et al. Inflammatory dysregulation of blood monocytes in Parkinson's disease patients. Acta Neuropathol (2014) 128(5):651-63. doi:10.1007/ s00401-014-1345-4

45. Funk N, Wieghofer P, Grimm S, Schaefer R, Bühring HJ, Gasser T, et al. Characterization of peripheral hematopoietic stem cells and monocytes in Parkinson's disease. Mov Disord (2013) 28(3):392-5. doi:10.1002/mds.25300

46. Prinz M, Priller J. Microglia and brain macrophages in the molecular age: from origin to neuropsychiatric disease. Nat Rev Neurosci (2014) 15:300-12. doi:10.1038/nrn3722

47. Gomez-Nicola D, Boche D. Post-mortem analysis of neuroinflammatory changes in human Alzheimer's disease. Alzheimers Res Ther (2015) 7(1):42. doi:10.1186/s13195-015-0126-1

48. Steinman RM. Lasker basic medical research award. Dendritic cells: versatile controllers of the immune system. Nat Med (2007) 13(10):1155-9. doi:10.1038/nm1643

49. Togo T, Akiyama H, Iseki E, Kondo H, Ikeda K, Kato M. Occurrence of T cells in the brain of Alzheimer's disease and other neurological diseases. $J$ Neuroimmunol (2002) 124:83-92. doi:10.1016/S0165-5728(01)00496-9

50. Monsonego A, Imitola J, Petrovic S, Zota V, Nemirovsky A, Baron R. Abetainduced meningoencephalitis is IFN-\{gamma\}-dependent and is associated with T cell-dependent clearance of Abeta in a mouse model of Alzheimer's disease. Proc Natl Acad Sci U S A (2006) 103:5048-53. doi:10.1073/ pnas. 0506209103

51. Lueg G, Gross CC, Lohmann H, Johnen A, Kemmling A, Deppe M, et al. Clinical relevance of specific T-cell activation in the blood and cerebrospinal 
fluid of patients with mild Alzheimer's disease. Neurobiol Aging (2015) 36(1):81-9. doi:10.1016/j.neurobiolaging.2014.08.008

52. Brochard V, Combadiere B, Prigent A, Laouar Y, Perrin A, Beray-Berthat V, et al. Infiltration of CD4+ lymphocytes into the brain contributes to neurodegeneration in a mouse model of Parkinson disease. J Clin Invest (2009) 119:182-92. doi:10.1172/JCI36470

53. Mosley RL, Hutter-Saunders JA, Stone DK, Gendelman HE. Inflammation and adaptive immunity in Parkinson's disease. Cold Spring Harb Perspect Med (2012) 2(1):a009381. doi:10.1101/cshperspect.a009381

54. Colton CA. Immune heterogeneity in neuroinflammation: dendritic cells in the brain. J Neuroimmune Pharmacol (2013) 8(1):145-62. doi:10.1007/ s11481-012-9414-8

55. Anandasabapathy N, Victora GD, Meredith M, Feder R, Dong B, Kluger C, et al. Flt3L controls the development of radiosensitive dendritic cells in the meninges and choroid plexus of the steady state mouse brain. J Exp Med (2011) 208:1695-705. doi:10.1084/jem.20102657

56. Hanly A, Petito CK. HLA-DR-positive dendritic cells of the normal human choroid plexus: a potential reservoir of HIV in the central nervous system. Hum Pathol (1998) 29(1):88-93. doi:10.1016/S0046-8177(98)90395-1

57. Pashenkov M, Huang YM, Kostulas V, Haglund M, Söderström M, Link H. Two subsets of dendritic cells are present in human cerebrospinal fluid. Brain (2001) 124(Pt 3):480-92. doi:10.1093/brain/124.3.480

58. McMenamin PG, Wealthall RJ, Deverall M, Cooper SJ, Griffin B. Macrophages and dendritic cells in the rat meninges and choroid plexus: three-dimensional localisation by environmental scanning electron microscopy and confocal microscopy. Cell Tissue Res (2003) 313:259-69. doi:10.1007/s00441-003-0779-0

59. Greter M, Heppner FL, Lemos MP, Odermatt BM, Goebels N, Laufer T, et al. Dendritic cells permit immune invasion of the CNS in an animal model of multiple sclerosis. Nat Med (2005) 11(3):328-34. doi:10.1038/nm1197

60. Bulloch K, Miller MM, Gal-Toth J, Milner TA, Gottfried-Blackmore A, Waters EM, et al. CD11c/EYFP transgene illuminates a discrete network of dendritic cells within the embryonic, neonatal, adult, and injured mouse brain. J Comp Neurol (2008) 508(5):687-710. doi:10.1002/cne.21668

61. Kaunzner UW, Miller MM, Gottfried-Blackmore A, Gal-Toth J, Felger JC, McEwen BS, et al. Accumulation of resident and peripheral dendritic cells in the aging CNS. Neurobiol Aging (2012) 33(4):681-93. doi:10.1016/j. neurobiolaging.2010.06.007

62. Monsonego A, Weiner HL. Immunotherapeutic approaches to Alzheimer's disease. Science (2003) 302(5646):834-8. doi:10.1126/science.1088469

63. Serrano-Pozo A, Gómez-Isla T, Growdon JH, Frosch MP, Hyman BT. A phenotypic change but not proliferation underlies glial responses in Alzheimer disease. Am J Pathol (2013) 182(6):2332-44. doi:10.1016/j.ajpath.2013.02.031

64. Butovsky O, Kunis G, Koronyo-Hamaoui M, Schwartz M. Selective ablation of bone marrow-derived dendritic cells increases amyloid plaques in a mouse Alzheimer's disease model. Eur J Neurosci (2007) 26(2):413-6. doi:10.1111/j.1460-9568.2007.05652.x

65. Town T, Laouar Y, Pittenger C, Mori T, Szekely CA, Tan J, et al. Blocking TGFbeta-smad2/3 innate immune signaling mitigates Alzheimer-like pathology. Nat Med (2008) 14:681-7. doi:10.1038/nm1781

66. Oberländer U, Pletinckx K, Döhler A, Müller N, Lutz MB, Arzberger T, et al. Neuromelanin is an immune stimulator for dendritic cells in vitro. $B M C$ Neurosci (2011) 12:116. doi:10.1186/1471-2202-12-116

67. Koutsilieri E, Lutz MB, Scheller C. Autoimmunity, dendritic cells and relevance for Parkinson's disease. J Neural Transm (2013) 120(1):75-81. doi:10.1007/ s00702-012-0842-7

68. Schmitt TL, Steger MM, Pavelka M, Grubeck-Loebenstein B. Interactions of the Alzheimer beta amyloid fragment (25-35) with peripheral blood dendritic cells. Mech Ageing Dev (1997) 94:223-32. doi:10.1016/S0047-6374(97)01866-6
69. Ciaramella A, Sanarico N, Bizzoni F, Moro ML, Salani F, Scapigliati G, et al. Amyloid beta peptide promotes differentiation of pro-inflammatory human myeloid dendritic cells. Neurobiol Aging (2009) 30(2):210-21. doi:10.1016/j. neurobiolaging.2007.06.007

70. Ciaramella A, Bizzoni F, Salani F, Vanni D, Spalletta G, Sanarico N, et al. Increased pro-inflammatory response by dendritic cells from patients with Alzheimer's disease. J Alzheimers Dis (2010) 19(2):559-72. doi:10.3233/ JAD-2010-1257

71. Ciaramella A, Salani F, Bizzoni F, Orfei MD, Langella R, Angelucci F, et al. The stimulation of dendritic cells by amyloid beta 1-42 reduces BDNF production in Alzheimer's disease patients. Brain Behav Immun (2013) 32:29-32. doi:10.1016/j.bbi.2013.04.001

72. Ciaramella A, Salani F, Bizzoni F, Pontieri FE, Stefani A, Pierantozzi M, et al. Blood dendritic cell frequency declines in idiopathic Parkinson's disease and is associated with motor symptom severity. PLoS One (2013) 8(6):e65352. doi:10.1371/journal.pone.0065352

73. Sallusto F, Lanzavecchia A. Efficient presentation of soluble antigen by cultured human dendritic cells is maintained by granulocyte/macrophage colony-stimulating factor plus interleukin 4 and downregulated by tumor necrosis factor alpha. J Exp Med (1994) 179(4):1109-18. doi:10.1084/jem.179.4.1109

74. Shortman K, Liu YJ. Mouse and human dendritic cell subtypes. Nat Rev Immunol (2002) 2:151-61. doi:10.1038/nri746

75. Ziegler-Heitbrock L, Ancuta P, Crowe S, Dalod M, Grau V, Hart DN, et al. Nomenclature of monocytes and dendritic cells in blood. Blood (2010) 116:e74-80. doi:10.1182/blood-2010-02-258558

76. Lynch MA, Mills KH. Immunology meets neuroscience - opportunities for immune intervention in neurodegenerative diseases. Brain Behav Immun (2012) 26(1):1-10. doi:10.1016/j.bbi.2011.05.013

77. Cao C, Lin X, Zhang C, Wahi MM, Wefes I, Arendash G, et al. Mutant amyloid-b-sensitized dendritic cells as Alzheimer disease vaccine. J Neuroimmunol (2008) 200:1-10. doi:10.1016/j.jneuroim.2008.05.017

78. Nabar NR, Yuan F, Lin X, Wang L, Bai G, Mayl J, et al. Cell therapy: a safe and efficacious therapeutic treatment for Alzheimer's disease in APP+PS1 mice. PLoS One (2012) 7(12):e49468. doi:10.1371/journal.pone.0049468

79. Wang F, Liu H, Shen X, Ao H, Moore N, Gao L, et al. Combined treatment of amyloid- $\beta 1-42$-stimulated bone marrow-derived dendritic cells plus splenocytes from young mice prevents the development of Alzheimer's disease in APPswe/PSENldE9 mice. Neurobiol Aging (2015) 36(1):111-22. doi:10.1016/j. neurobiolaging.2014.06.029

80. Fisher Y, Nemirovsky A, Baron R, Monsonego A. Dendritic cells regulate amyloid- $\beta$-specific $\mathrm{T}$-cell entry into the brain: the role of perivascular amyloid- $\beta$. J Alzheimers Dis (2011) 27(1):99-111. doi:10.3233/ JAD-2011-102034

81. Ugen KE, Lin X, Bai G, Liang Z, Cai J, Li K, et al. Evaluation of an $\alpha$ synuclein sensitized dendritic cell based vaccine in a transgenic mouse model of Parkinson disease. Hum Vaccin Immunother (2015) 11(4):922-30. doi:10.108 0/21645515.2015.1012033

Conflict of Interest Statement: The authors declare that the research was conducted in the absence of any commercial or financial relationships that could be construed as a potential conflict of interest.

Copyright $\odot 2015$ Bossù, Spalletta, Caltagirone and Ciaramella. This is an open-access article distributed under the terms of the Creative Commons Attribution License (CC BY). The use, distribution or reproduction in other forums is permitted, provided the original author(s) or licensor are credited and that the original publication in this journal is cited, in accordance with accepted academic practice. No use, distribution or reproduction is permitted which does not comply with these terms. 